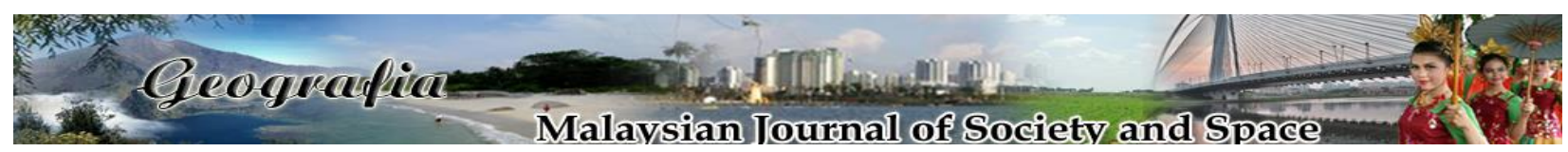

\title{
Persepsi golongan belia terhadap 'Malaysia Baharu' dalam kerangka pembangunan komuniti di Semenanjung Malaysia
}

\author{
Mohd Mahadee Ismail $^{1}$, Mohd Sabri Md Nor ${ }^{1}$, Zatul Himmah Adnan ${ }^{1}$ \\ ${ }^{1}$ Jabatan Pengajian Kenegaraan dan Ketamadunan, Fakulti Ekologi Manusia, Universiti Putra Malaysia. \\ Correspondence: Mohd Mahadee Ismail (email: mahadee@upm.edu.my)
}

Received: 15 November 2019; Accepted: 22 November 2019; Published: 25 November 2019

\begin{abstract}
Abstrak
Makalah ini membincangkan tentang persepsi golongan belia terhadap 'Malaysia Baharu' dalam kerangka pembangunan komuniti di Semenanjung Malaysia. Istilah Malaysia Baharu popular digunakan selepas berlakunya pertukaran kerajaan pada pilihan raya umum ke-14 daripada parti Barisan Nasional yang mendominasi pemerintahan negara sejak merdeka kepada kerajaan baru yang diterajui oleh Pakatan Harapan. Malaysia yang dikatakan melalui fasa baru dijangka mengalami perubahan dari segenap aspek kehidupan politik, ekonomi dan sosiobudaya ke arah yang lebih baik. Dari itu, satu kajian telah dijalankan dalam kalangan belia khususnya mahasiswa universiti awam di Semenanjung Malaysia. Kajian ini bertujuan untuk mengenalpasti persepsi mereka terhadap perkembangan semasa yang berlaku dalam negara ini. Kajian telah menggunakan gabungan dua pendekatan kualitatif dan kuantitatif. Untuk pendekatan kualitatif, teknik NGT (Teknik Berkumpulan Nominal) dan FGD (Perbincangan Kumpulan Berfokus) telah dilaksanakan, manakala bagi pendekatan kuantitatif pula teknik survey menggunakan borang soal selidik. Borang soal selidik telah diedarkan kepada 800 orang responden belia pelbagai etnik. Hasil kajian menunjukkan wujud variasi persepsi responden berdasarkan etnik terhadap Malaysia Baharu dalam perkara-perkara yang melibatkan pembangunan komuniti. Golongan belia etnik Melayu dilihat lebih objektif dalam mengemukakan pandangan mereka manakala golongan belia etnik Cina dan India pula dilihat lebih positif dalam menunjukkan sokongan mereka terhadap era pemerintahan Malaysia Baharu ini. Hasil kajian ini juga memberikan suatu gambaran terkini terhadap perkembangan semasa yang berlaku walaupun Malaysia Baharu itu baru sahaja berusia setahun jagung.
\end{abstract}

Kata kunci: belia, etnisiti, mahasiswa universiti awam, malaysia baharu, pembangunan komuniti, semenanjung Malaysia. 


\title{
Youth perception towards 'New Malaysia' in the framework of community development in Peninsular Malaysia
}

\begin{abstract}
This paper discusses the perception of the youth towards New Malaysia in the framework of community development in Peninsular Malaysia. The term 'New Malaysia' is popular to be used after the change of government's in the $14^{\text {th }}$ general election from the Barisan Nasional party that dominated the country's government since independence to the new government led by Pakatan Harapan. Malaysia, which is said to undergoes new phase, is expected to experience changes from various aspects of political, economic and social-cultural life to a better one. Therefore, the study was conducted among youth, especially public university students in Peninsular Malaysia. The study aims to identify their perception of the current developments in the country. The research used qualitative and quantitative approaches. For qualitative approach, NGT (Nominal Group Technique) and FGD (Focus Group Discussion) techniques were adopted, while for quantitative approach, survey techniques using questionnaire forms were employed. The questionnaire was distributed to 800 youth respondents of various ethnic groups. The findings show that there are a variety of perceptions based on the ethnicity of the respondents to New Malaysia in the matters involving community development. The Malays were seen as more objective in their views while the Chineses and Indians were more positive in expressing their support for the New Malaysian government. The findings also provide the latest overview of current developments even though the New Malaysia is just about two years old.
\end{abstract}

Keywords: youth, ethnicity, public university students, new malaysia, community development, peninsular Malaysia.

\section{Pengenalan}

Golongan belia adalah pemangkin masa depan negara. Mereka bukan sahaja sebagai generasi pelapis kepimpinan negara tetapi mereka juga adalah pencetus dan pendukung segala bentuk perubahan yang berlaku dalam negara. Golongan belia dikatakan telah menjadi tulang belakang kepada berlakunya perubahan tampuk pemerintahan negara pada pilihan raya umum ke-14 yang lalu. Kesinambungan dari itu, golongan belia dilihat terus aktif terlibat secara langsung mahupun tidak langsung dalam menyumbang kepada pembangunan negara menerusi pelbagai bidang yang diceburi dengan kepakaran dan kemahiran masing-masing. Walaupun sebahagian besar daripada umur mereka masih lagi berada di alam pendidikan, namun sumbangan mereka tetap membawa makna yang amat besar kepada kelestarian masa depan negara.

Perkembangan terkini di Malaysia telah mentakrifkan golongan belia adalah kumpulan individu yang berusia 15 hingga 30 tahun. Sebelum ini, berdasarkan Dasar Pembangunan Belia Negara serta Akta Belia dan Pembangunan Belia 2007 telah mentakrifkan golongan belia adalah individu dalam usia 15 hingga 40 tahun (Utusan Online, 2014; MalaysiaKini, 2019). Perubahan had umur tersebut tidak membawa apa-apa implikasi langsung terhadap struktur dan bentuk masyarakat tetapi telah memberikan kesan kepada program-program pembangunan belia dan pertubuhan-pertubuhan belia (MalaysiaKini, 2019). Perubahan had umur belia dengan takrifan 
baru tersebut dilihat sebagai satu tindakan untuk memperkasa kelompok ini bersesuaian dengan perubahan dan perkembangan kontemporari yang berlaku di arena antarabangsa.

Di era Malaysia Baharu ini, golongan belia dilihat menaruh harapan yang cukup tinggi untuk melihat perubahan yang lebih baik dalam segenap aspek kehidupan terutamanya perkaraperkara yang berkait rapat dengan mereka. Mereka cukup teruja untuk melihat impak yang lebih positif dalam pembangunan negara umumnya dan pembangunan komuniti setempat khususnya. Mereka juga cukup ghairah dalam membincangkan perkara-perkara yang menjadi dasar kerajaan baru menerusi pelbagai medium perantara khususnya media sosial. Justeru itu, pengaruh dan pandangan golongan belia tidak lagi boleh dipandang remeh. Setiap perkara yang diketengahkan mereka perlu diteliti, diperhalusi dan dinilai dengan bijaksana.

Sehubungan dengan itu, memandangkan idea dan slogan Malaysia Baharu ini masih lagi baru dan belum terdapat kajian bersifat empirikal yang membincangkan tentang perkara ini, maka adalah tepat pada waktunya kajian ini cuba untuk merungkai persoalan persepsi semasa golongan belia terhadap Malaysia Baharu khususnya dalam kerangka pembangunan komuniti di Semenanjung Malaysia.

\section{Tinjauan literatur}

Tinjauan literatur artikel ini dibahagikan kepada dua bahagian utama iaitu tentang Malaysia Baharu dan pembangunan komuniti. Perbincangan tentang Malaysia Baharu lebih terarah kepada bentuk perubahan yang berlaku di dalam negara dan harapan rakyat, manakala perbincangan tentang pembangunan komuniti lebih tertumpu kepada konsep asas dan konstruk-konstruk utama yang menjadi indikator dan membentuk kerangka pembangunan komuniti.

\section{'Malaysia baharu'}

'Malaysia Baharu' ialah suatu bentuk idea, slogan atau gagasan yang diperkenalkan sejurus sahaja Pakatan Harapan berjaya mengambil alih tampuk pemerintahan negara daripada parti Barisan Nasional yang telah mendominasi pemerintahan negara sejak merdeka sehinggalah pilihan raya umum ke-14 yang lalu. Dalam pilihan raya umum yang diadakan pada 9 Mei 2018, Pakatan Harapan berjaya memenangi sebanyak 121 kerusi parlimen, Barisan Nasional telah memenangi sebanyak 79 kerusi parlimen manakala PAS hanya memenangi sebanyak 18 kerusi parlimen sahaja. Dari itu Pakatan Harapan berjaya membentuk kerajaan dengan majoriti mudah mengatasi semua parti lain yang bertanding. Sempena berlakunya pertukaran kerajaan dan berubahnya landskap politik negara, maka muncullah istilah Malaysia Baharu sebagai suatu ungkapan bagi menggambarkan peralihan tampuk pemerintahan negara daripada sebuah orde lama yang kebal berkuasa selama ini kepada sebuah orde baru yang banyak membawa aspirasi rakyat. Perkembangan tersebut juga seolah-olah membawa satu nafas baru dalam negara yang baru dilahirkan semula (Berita Harian Online, 2018) dengan bentuk kepimpinan dan pemerintahan negara yang lebih telus serta bersih. Sebagai perumpamaan ungkapan Malaysia Baharu ibarat seperti sebuah rumah lama yang dicat baru, ditukar dengan perabot baru dan dihiasi dengan pelbagai aksesori baru.

Malaysia Baharu adalah hasil tindakan kolektif untuk memperbaiki apa yang dikatakan telah rosak sebelum ini. Seperti mana yang ditegaskan oleh Perdana Menteri Malaysia, Tun Dr Mahathir Mohamad, terbentuknya gabungan melalui Pakatan Harapan adalah bertujuan untuk 
"menyelamatkan Malaysia dari kerajaan yang terkenal sebagai kleptokrasi, masa depan negara akan menjadi amat buruk dan rakyat akan terus menderita. Besar kemungkinan Malaysia akan menjadi apa yang dipanggil sebagai failed state atau negara gagal" (Berita Harian Online, 2019). Kerajaan baru Pakatan Harapan telah melaksanakan pelbagai tindakan pemulihan negara menerusi penyiasatan menyeluruh tentang isu $1 \mathrm{MDB}$, penguatkuasaan undang-undang yang lebih tegas terhadap penyalahgunaan kuasa, penstrukturan semula Tabung Haji dan FELDA, pemerkasaan Suruhanjaya Pencegahan Rasuah Malaysia dan penubuhan GIACC atau Pusat Governans, Integriti dan Anti-Rasuah Nasional bagi meningkat integriti dan pengenalan Pelan Anti-Rasuah Nasional (Berita Harian Online, 2019). Selain itu, kerajaan baru pimpinan Tun Dr Mahathir Mohamad telah mengkaji semula projek-projek mega kerajaan terdahulu seperti ECRL dan MRT3 yang dilihat menambah bebanan kewangan negara (Berita Harian Online, 2019). Rundingan semula kontrak-kontrak kerajaan terdahulu telah berjaya menyelamatkan kewangan negara sebanyak RM22.8 billion (Berita Harian Online, 2019).

Dalam pada itu, kerajaan di era Malaysia Baharu ini turut melaksanakan reformasi undangundang. Undang-undang yang dilihat zalim dan menekan rakyat telah dibatalkan (Berita Harian Online, 2019). Pelaksanaan hukuman bunuh telah dihentikan buat sementara dan sedang dikaji semula, undang-undang berkaitan berita palsu dalam proses untuk dibatalkan dan media telah diberikan kebebasan yang lebih luas (Berita Harian Online, 2019) dalam melaporkan sebarang bentuk berita. Doktrin pengasingan kuasa seperti mana yang termaktub dalam Perlembagaan Persekutuan telah dipraktikkan sepenuhnya melalui badan eksekutif, legislatif dan kahakiman (Berita Harian Online, 2019). Rakyat menaruh harapan yang cukup besar untuk melihat tidak berlaku campurtangan antara ketiga-tiga badan pemerintahan tersebut yang menjadi nadi pemerintahan negara (Utusan Online, 2018).

Kerajaan di era Malaysia Baharu juga telah memulakan semula langkah ke arah membina negara yang progresif dan berdaya maju dalam mencapai ketamadunan berperadaban tinggi menerusi agenda Wawasan Kemakmuran Bersama atau Shared Prosperity. Wawasan Kemakmuran Bersama merupakan satu inisiatif bagi merealisasikan "Malaysia sebagai sebuah negara yang terus menerus membangun secara mampan seiring dengan pengagihan ekonomi yang adil dan inklusif di setiap peringkat rantaian nilai, kelas, kaum dan geografi sehingga mewujudkan rasa keharmonian dan kestabilan dalam kalangan rakyat menjelang tahun 2030" (Tun Dr Mahathir Mohamad, Berita Harian Online, 2019). Wawasan tersebut selaras dengan aspirasi rakyat untuk melihat wujudnya perpaduan antara kumpulan etnik yang lebih kukuh (Utusan Online, 2018) memandangkan mutakhir ini banyak isu-isu yang mencemaskan dan boleh melahirkan kebencian antara etnik. Walaupun rakyat Malaysia sentiasa meraikan kepelbagaian, tetapi hakikatnya isu perkauman sentiasa menjadi duri dalam daging (Utusan Online, 2018) yang boleh menggugat keharmonian negara. Keharmonian yang terbina selama ini adalah atas faktor saling percaya dan hormat menghormati antara satu sama lain. Sekiranya perasaan saling percaya dan sikap hormat semakin pudar, negara mungkin mengundang risiko seperti mana yang telah berlaku pada 13 Mei 1969.

Rakyat mengharapkan kerajaan Malaysia Baharu akan menunaikan segala janji yang dibentangkan dalam manifesto pilihan raya lalu seperti mana yang terkandung di dalam Buku Harapan: Membina Negara Memenuhi Harapan. Antara lain kerajaan berjanji untuk menghapuskan tol, membatalkan pelaksanaan AES, menurunkan harga runcit petrol, menyediakan rumah mampu milik, menyediakan lebih banyak peluang pekerjaan dan pelbagai lagi. Menurut Tun Dr Mahathir, kerajaan memerlukan masa dalam usaha untuk melunaskan janji-janji pilihan raya (Berita Harian Online, 2019). Tun Dr Mahathir turut menegaskan... 
“...prestasi semasa pencapaian Janji Kerajaan bagi tempoh 10 Mei 2018 sehingga 30 April 2019 adalah sebanyak 39.01\% yang diukur melalui status kemajuan 464 Inisiatif. Sebanyak 53 Inisiatif atau 11.42\% telah ditunaikan dari 128 Inisiatif. Manakala 283 Inisiatif atau $60.99 \%$ adalah di peringkat Dalam Perancangan atau Belum Mula. Prestasi ini menunjukkan peningkatan sebanyak $29.34 \%$ berbanding 9.67\% pada 31 Disember 2018” (Berita Harian Online, 2019).

Kerajaan Malaysia Baharu turut memberikan penekanan terhadap kaum wanita serta golongan belia untuk melibatkan diri secara langsung dalam hal ehwal pentadbiran negara dan terlibat sama sebagai pembuat dasar kerajaan. Sebagai contoh, beberapa jawatan penting telah diberikan kepada kaum wanita seperti Ketua Hakim Negara, Gabenor Bank Negara, Ketua Suruhanjaya Pencegahan Rasuah Malaysia dan pelbagai jawatan lain dalam syarikat berkaitan kerajaan (GLC) (Berita Harian Online, 2019). Begitu juga dengan perlantikan jawatan-jawatan utama kerajaan yang diisi oleh golongan belia. Tindakan sedemikian sebagai anjakan baru dalam usaha untuk terus memperkasa golongan wanita dan belia di dalam arus pembangunan negara. Peluang tersebut menarik keyakinan golongan wanita dan belia terhadap kerajaan baru yang dikatakan lebih prihatin dengan permasalahan yang dihadapi oleh rakyat.

Dalam menyediakan perumahan mampu milik, kerajaan Malaysia Baharu telah mengambil inisiatif dengan menubuhkan Majlis Perumahan Mampu Milik Kebangsaan yang dipengerusikan sendiri oleh Perdana Menteri (Berita Harian Online, 2019). Majlis tersebut bertanggungjawab membina satu juta rumah mampu milik dan menyelenggara pengkalan data terbuka rumah mampu milik yang masih belum dijual (Berita Harian Online, 2019). Inisiatif ini diambil sebagai salah satu usaha kerajaan dalam membela kebajikan kumpulan berpendapatan rendah untuk memiliki rumah sendiri dan mengurangkan kadar kemiskinan bandar serta luar bandar. Selaras dengan itu, pihak kerajaan juga telah menetapkan kadar gaji minimum pada RM1,050 sebulan atau RM5.05 sejam bersandarkan kedudukan semasa kewangan negara.

Pada 1 September 2018, pihak kerajaan telah memperkenalkan Cukai Jualan dan Perkhidmatan (SST) bagi menggantikan Cukai Barang dan Perkhidmatan (GST) seperti yang dijanjikan dalam pilihan raya lepas. Mekanisme cukai baru ini cuba untuk mengurangkan kadar kenaikan harga barang dan perkhidmatan yang mana rakyat dikatakan telah terbeban dengan pelaksanaan GST. GST dikenakan pada satu kadar sahaja manakala kadar SST adalah berbeza antara cukai jualan dan cukai perkhidmatan (Utusan Online, 2018). Pelaksanaan SST dikatakan lebih memudahkan para peniaga dan tidak membebankan pengguna oleh kerana ia tidak melibatkan semua produk. SST hanya dikenakan terhadap produk-produk terpilih sahaja (Utusan Online, 2018).

Di era Malaysia Baharu rakyat turut mengharapkan wujudnya budaya politik yang lebih matang, profesional, rasional dan lebih adil (Utusan Online, 2018) di samping menuntut tadbir urus kerajaan yang lebih efisyen dalam semua aspek pemerintahan. Pelaksanaan programprogram pembangunan perlu memberikan keutamaan kepada kumpulan sasar yang lebih memerlukan (Berita Harian Online, 2018). Soal pilih kasih, kronisme, nepotisme dan kecenderungan salah guna kuasa seharusnya dijadikan batasan dan sempadan terbaik dalam memastikan pelaksanaan tadbir urus yang lebih telus dan berintegriti bersesuaian dengan nafas baru yang diberikan melalui Malaysia Baharu hari ini. 


\section{Pembangunan komuniti}

Pembangunan komuniti merupakan suatu kerangka yang besar dalam pembangunan masyarakat setempat. Pembangunan masyarakat setempat yang dimaksudkan melibatkan pelbagai aspek kehidupan iaitu politik, ekonomi, sosiobudaya dan infrastruktur awam. Apa yang nyata, tujuan utama pembangunan komuniti ialah untuk memperbaiki dan meningkatkan taraf serta kualiti hidup masyarakat di sesuatu tempat ke arah yang lebih baik sesuai dengan perubahan dan perkembangan semasa. Bagi Fendley dan Christenson (2009), tujuan pembangunan komuniti adalah untuk membantu masyarakat setempat memperbaiki keadaan hidup sosial dan ekonomi mereka yang lebih sempurna. Dari itu, konsep dan pendekatan pembangunan komuniti di antara satu tempat dengan tempat yang lain mungkin berbeza walaupun kadang kalanya sama. Hal ini kerana konsep dan pendekatan pembangunan komuniti amat bergantung kepada lokasi, budaya, masyarakat yang terlibat (Mohammad Shatar, 2003), persekitaran sosial dan keperluan masyarakat. Apa yang lebih penting, pembangunan komuniti cuba untuk membantu masyarakat setempat keluar daripada permasalahan biasa yang dihadapi oleh mereka melalui pelbagai bentuk program dan projek pembangunan. Bertepatan dengan apa yang ditakrifkan oleh Ploch (1976) yang meletakkan pembangunan komuniti sebagai "penglibatan aktif daripada masyarakat setempat untuk menjalankan program-program yang dapat meningkatkan kualiti kehidupan mereka" (dipetik dari Mohammad Shatar, 2003).

Bagi Sanders (1989), pembangunan komuniti boleh dilihat dari empat perspektif yang berbeza iaitu proses, kaedah atau cara, program dan gerakan. Berbeza dengan apa yang diketengahkan oleh Phillips dan Pittman (2009), dan Haines (2009), pembangunan komuniti dilihat sebagai suatu proses dan hasil. Proses melibatkan keupayaan komuniti untuk bertindak secara kolektif dan mempertingkatkan keupayaan untuk melaksanakan sesuatu manakala hasil melibatkan penambahbaikan segala aspek fizikal, sosial dan ekonomi dalam sesebuah komuniti (Phillips \& Pittman, 2009). Hope (1980) melihat "pembangunan komuniti sebagai suatu proses yang melibatkan pengenalpastian masalah dan penyelesaian masalah yang dihadapi tersebut" (dipetik dari Mohammad Shatar, 2003: 136). Sementara itu, Haines (2009) memberikan penekanan pembangunan komuniti sebagai usaha dan tindakan untuk memperkasa kapasiti sesebuah komuniti dalam menentukan keutamaan serta peluang yang memupuk perubahan positif dalam konteks kejiranan. Pembangunan komuniti turut melibatkan pembangunan aset dalam mempertingkatkan kualiti hidup penduduk yang berpendapatan rendah ke arah berpendapatan sederhana (Haines, 2009). Selain itu, pembangunan komuniti juga boleh dilihat sebagai usaha terancang untuk menghasilkan sesuatu aset yang dapat meningkatkan kapasiti penduduk bagi memperbaiki kualiti hidup mereka (Haines, 2009). Dalam pada itu, pembangunan komuniti adalah suatu pendekatan berasaskan tempat yang menumpukan pembangunan aset di mana masyarakat setempat akan mendapat faedah daripada pembangunan yang dilaksanakan tersebut (Haines, 2009). Namun begitu, menurut Ahmad Shukri (2015), dalam konteks Malaysia pembangunan komuniti tidak boleh terlepas dari pengaruh identiti budaya di mana pengamalan budaya yang berbeza akan mencorakkan bentuk pembangunan yang dilaksanakan.

Dari itu, berdasarkan kepada penghuraian konsep pembangunan komuniti di atas, dapat dirumuskan bahawa pembangunan komuniti adalah sebagai suatu usaha dan tindakan kolektif terancang setiap peringkat masyarakat untuk memperbaiki dan mempertingkatkan kualiti hidup mereka ke arah yang lebih baik melibatkan pembangunan pelbagai dimensi kehidupan. Dalam menjayakan projek dan program pembangunan komuniti, ia melibatkan banyak pihak 
berkepentingan khususnya pihak kerajaan, pertubuhan bukan kerajaan, pihak swasta, komuniti setempat termasuklah orang awam.

Secara lebih spesifik, Mohammad Shatar (2003) telah mengetengahkan beberapa elemen utama pembangunan komuniti iaitu pembangunan ekonomi, kepimpinan, perumahan, infrastruktur, pendidikan, kesihatan, pertanian dan lain-lain perkara yang diperlukan oleh masyarakat. Sehubungan dengan itu, dalam menilai persepsi golongan belia terhadap Malaysia Baharu dalam kerangka pembangunan komuniti, kajian ini telah memfokuskan kepada empat dimensi utama merangkumi; (i) politik dan sistem pemerintahan; (ii) keadaan ekonomi; (iii) sosio-kehidupan; dan (iv) perkembangan pendidikan dan kemudahan awam.

\section{Metodologi kajian}

Pendekatan kajian ini melibatkan aplikasi kaedah kualitatif dan kuantitatif yang boleh dikategorikan kepada tiga peringkat utama. Peringkat pertama dan kedua kajian ini telah mengaplikasi pendekatan kualitatif melalui kaedah nominal group technique (NGT) dan focus group discussion (FGD). Sementara itu, peringkat ketiga kajian ini mengaplikasi pendekatan kuantitatif melalui teknik survey menggunakan borang soal selidik.

Pada peringkat pertama, kajian ini telah mengaplikasi metod NGT bagi memperolehi data awal (data asas) tentang persepsi golongan belia (mahasiswa universiti awam) terhadap Malaysia Baharu dalam kerangka pembangunan komuniti. NGT merupakan kaedah yang amat bersesuaian dalam menentukan peringkat keutamaan idea daripada informan dalam membuat interpretasi terhadap sesuatu keadaan yang wujud khususnya tentang sesuatu perkara baru. Informan yang terlibat terdiri daripada 10 orang mahasiswa Universiti Pendidikan Sultan Idris (UPSI) yang dipilih dari pelbagai etnik dan aliran pengajian. Cara pemilihan informan adalah menggunakan kaedah pensampelan bertujuan. Melalui NGT, para informan diberi peluang untuk bersuara dan berkongsi pandangan serta idea mereka terhadap sesuatu perkara atau persoalan yang dikemukakan. Idea dan pandangan mereka dikongsi bersama dengan semua informan lain dengan cara menulis di atas kertas dan menerangkannya dalam bentuk round-robin atau bergilirgilir. Kemudian, idea dan pandangan mereka telah dibincangkan supaya lebih jelas dan menepati maksud sebenar. Dalam proses ini, idea yang sama telah digabungkan berdasarkan persamaan dan kesesuaian tema-tema tertentu. Seterusnya, setiap pilihan akan ditentukan keutamaannya melalui proses ranking. Akhirnya, setelah proses ranking kali kedua dilaksanakan, sepuluh idea yang diberi ranking tertinggi akan dibincangkan semula untuk mendapatkan persetujuan setiap informan. Data kualitatif yang dikumpulkan melalui NGT telah dianalisis dengan cara analisis kandungan mengikut keutamaan yang telah dipersetujui oleh semua informan yang terlibat.

Pada peringkat kedua, kajian ini telah melaksanakan FGD bagi mendapatkan pengesahan tentang pandangan dan idea yang telah dikemukakan oleh informan NGT dan membincangkan dengan lebih mendalam tentang persepsi belia (mahasiswa universiti awam) terhadap Malaysia Baharu dalam kerangka pembangunan komuniti. FGD melibatkan seramai 10 orang belia yang terdiri daripada mahasiswa Universiti Putra Malaysia (UPM) yang juga dipilih dari pelbagai etnik dan aliran pengajian. Cara pemilihan informan juga menggunakan kaedah pensampelan bertujuan bagi memastikan informan yang terlibat berada dalam kategori kumpulan sasaran sebenar. Kumpulan belia tersebut dipecahkan kepada dua kumpulan bagi memberikan peluang yang secukupnya kepada setiap informan untuk mengemukakan idea dan pandangan mereka terhadap perkara-perkara yang diketengahkan. Hasil dapatan FGD telah dianalisis dan 
dikelompokkan kepada tema-tema tertentu mengikut kesesuaian dimensi dan konstruk yang akan digunakan bagi mencapai semua objektif kajian.

Pada peringkat ketiga, setelah selesai pelaksanaan NGT dan FGD, data yang diperoleh telah digunakan untuk membentuk dimensi dan konstruk dalam borang soal selidik melalui kaedah kuantitatif. Analisis deskriptif telah digunakan untuk memperkukuhkan data yang diperoleh melalui kaedah NGT dan FGD. Ini bermakna, semua konstruk yang dibentuk dalam borang soal selidik adalah hasil dari dapatan NGT dan FGD, serta segala bentuk maklumat yang dikemukakan adalah dari pandangan golongan belia sendiri. Pelaksanaan kaedah kuantitatif melalui teknik survey ini penting supaya data tersebut dapat di generalisasi dalam kelompok yang lebih luas. Borang soal selidik telah diedarkan kepada 800 orang responden yang terdiri daripada golongan belia mahasiswa universiti awam terpilih di Semenanjung Malaysia melibatkan empat zon utama; (a) Zon Utara (USM, UUM \& UNIMAP); (b) Zon Timur (UMK \& UMT); (c) Zon Tengah (UPM, UM \& UKM); dan (d) Zon Selatan (UTM, UTHM \& UTEM). Setiap zon melibatkan responden seramai 200 orang mahasiswa yang dipilih dari kepelbagaian kumpulan etnik dan latar belakang aliran pengajian. Pentingnya mengambil sampel dari setiap zon yang ditetapkan bertujuan untuk melihat variasi persepsi golongan belia terhadap Malaysia Baharu berasaskan kepada persekitaran dan suasana pendedahan pembelajaran mereka. Dalam hal ini, faktor lokasi pusat pembelajaran dijangka menjadi salah satu elemen yang menentukan persepsi golongan belia terhadap persoalan yang dikaji.

Saiz sampel yang melibatkan responden secara menyeluruh dari universiti awam terpilih di Semenanjung Malaysia ini dijangka dapat memberi gambaran yang lebih tepat tentang dapatan kajian yang bakal diperoleh. Teknik pensampelan berstrata telah digunakan untuk menentukan sampel kajian. Responden telah kategorikan kepada strata etnik berdasarkan kepada nisbah populasi penduduk Malaysia iaitu 60\% etnik Melayu dan Bumiputera, 25\% etnik Cina, 10\% etnik India dan 5\% lain-lain. Pecahan responden seramai 800 orang tersebut pula mengambil kira faktor etnisiti mengikut pecahan seperti berikut; (a) Melayu dan Bumiputera 60\% (n=480); (b) Cina 25\% ( $n=200)$; (c) India 10\% ( $=80)$; dan lain-lain 5\% ( $=40)$. Kajian ini mengambil kira faktor etnik sebagai salah satu indikator dalam mempengaruhi persepsi golongan belia yang dikaji. Ini kerana kumpulan etnik yang berbeza biasanya mempunyai pandangan semesta yang berbeza-beza terhadap sesuatu perkara (Mansor, 2012).

\section{Hasil kajian dan perbincangan}

Secara umumnya, wujud variasi persepsi golongan belia yang dikaji berdasarkan kepada kumpulan etnik terhadap Malaysia Baharu dalam kerangka pembangunan komuniti di Semenanjung Malaysia. Wujudnya perbezaan persepsi ini adalah sesuatu yang lumrah dalam senario kepelbagaian masyarakat sepertimana yang terdapat di Malaysia. Mereka bukan sahaja berbeza daripada segi kumpulan etnik, agama, bahasa, budaya dan norma hidup tetapi mereka juga telah melalui pengalaman sosialisasi yang berbeza-beza (Mohd Mahadee, 2015). Mereka juga turut terpisah daripada segi pendidikan asas yang diterima memandangkan wujudnya sekolah kebangsaan dan sekolah jenis kebangsaan. Perkembangan sedemikian bukanlah sesuatu kelemahan kepada negara tetapi boleh dijadikan sesuatu kekuatan negara yang sentiasa meraikan perbezaan dan kepelbagaian. Situasi sedemikian juga menunjukkan masyarakat kita semakin hari semakin matang dan sentiasa berlapang dada dalam menerima setiap perbezaan yang wujud dalam masyarakat. 
Variasi persepsi golongan belia yang dikaji terhadap Malaysia Baharu dalam konteks pembangunan komuniti dapat dilihat dengan lebih terperinci dalam Jadual 1, 2, 3 dan 4. Hasil dari kajian ini akan dikupas satu-persatu dalam meneliti pola persepsi golongan belia masa kini khususnya dalam kalangan belia terpelajar iaitu mahasiswa universiti awam di Semenanjung Malaysia.

Jadual 1. Persepsi terhadap politik dan sistem pentadbiran

\begin{tabular}{|c|c|c|c|c|c|c|c|c|}
\hline \multirow[b]{3}{*}{ Perkara } & \multicolumn{8}{|l|}{ Etnik } \\
\hline & \multicolumn{2}{|l|}{ Melayu } & \multicolumn{2}{|l|}{ Cina } & \multicolumn{2}{|l|}{ India } & \multicolumn{2}{|c|}{ Lain-lain } \\
\hline & $\begin{array}{l}\text { Setuju } \\
(\%)\end{array}$ & $\begin{array}{l}\text { Tidak } \\
\text { Setuju } \\
(\%)\end{array}$ & $\begin{array}{l}\text { Setuju } \\
(\%)\end{array}$ & $\begin{array}{l}\text { Tidak } \\
\text { Setuju } \\
(\%)\end{array}$ & $\begin{array}{l}\text { Setuju } \\
(\%)\end{array}$ & $\begin{array}{l}\text { Tidak } \\
\text { Setuju } \\
(\%)\end{array}$ & $\begin{array}{l}\text { Setuju } \\
(\%)\end{array}$ & $\begin{array}{l}\text { Tidak } \\
\text { Setuju } \\
(\%)\end{array}$ \\
\hline Literasi politik semakin tinggi & 52.5 & 21 & 8.75 & 4.87 & 6 & 2.5 & 3.25 & 1.13 \\
\hline $\begin{array}{l}\text { Pemerintahan baru menjunjung } \\
\text { prinsip keadilan }\end{array}$ & 29.25 & 44.25 & 9.63 & 4 & 6.5 & 2 & 2.37 & 2 \\
\hline $\begin{array}{l}\text { Pentadbiran telus dan bebas } \\
\text { rasuah }\end{array}$ & 33.25 & 40.25 & 8.87 & 4.75 & 5.63 & 2.87 & 2.13 & 2.25 \\
\hline $\begin{array}{l}\text { Prinsip demokrasi lebih } \\
\text { menyeluruh }\end{array}$ & 36.75 & 36.75 & 10.37 & 3.25 & 6.5 & 2 & 2.63 & 1.75 \\
\hline Nilai integriti lebih tinggi & 35.5 & 38 & 10.37 & 3.25 & 6.13 & 2.37 & 2.75 & 1.63 \\
\hline Masyarakat peka isu-isu politik & 55.5 & 18 & 10.13 & 3.5 & 6.87 & 1.62 & 3.13 & 1.25 \\
\hline
\end{tabular}

Sumber: Kajian lapangan, 2019

Hasil kajian menunjukkan bahawa golongan belia berpandangan di era Malaysia Baharu ini tahap literasi politik dalam kalangan masyarakat Malaysia semakin tinggi. Ini dapat dilihat dalam Jadual 1 yang menunjukkan lebih dari separuh bilangan responden tidak kira daripada kumpulan etnik mana sekalipun menyatakan sokongan terhadap perkara ini. Mereka sedar bahawa perkembangan ini adalah sesuatu yang positif berlaku dalam konteks pembangunan komuniti di era Malaysia Baharu hari ini. Perkembangan ini juga selaras dengan senario politik semasa yang berlaku dalam negara. Akan tetapi, rata-rata golongan belia etnik Melayu berpandangan pemerintahan di era Malaysia Baharu ini belum benar-benar menjunjung prinsip keadilan berbanding dengan kumpulan belia etnik Cina dan India yang melihat pemerintahan di era Malaysia Baharu kini telah pun menjunjung prinsip keadilan.

Begitu juga dalam aspek pentadbiran telus dan bebas rasuah, rata-rata golongan belia etnik Melayu berpandangan bahawa pentadbiran baharu ini masih belum sepenuhnya telus dan bebas rasuah. Sebaliknya, kumpulan belia etnik Cina dan India yang lebih dari separuh melihat pentadbiran kini lebih telus dan bebas rasuah berbanding dengan pentadbiran kerajaan terdahulu. Hasil kajian ini juga seiring dengan pandangan golongan belia terhadap nilai integriti. Lebih dari separuh golongan belia etnik Melayu yang berpandangan di era Malaysia Baharu, nilai integriti masih belum benar-benar tinggi berbanding dengan pandangan kumpulan belia etnik Cina, India dan lain-lain kumpulan etnik yang melihat nilai integriti di era Malaysia Baharu ini adalah lebih tinggi. Situasi ini menunjukkan wujud perbezaan persepsi dan pandangan antara kumpulan belia Melayu dan bukan Melayu.

Dalam konteks pengamalan prinsip demokrasi yang lebih menyeluruh, hanya sebahagian daripada golongan belia etnik Melayu yang bersetuju dengan perkara ini manakala sebahagian lagi tidak bersetuju. Namun begitu, lebih dari separuh belia kumpulan etnik Cina, India termasuk lain-lain kumpulan etnik yang berpandangan bahawa di era Malaysia Baharu ini, prinsip demokrasi diamalkan dengan lebih menyeluruh. 
Apa yang lebih menarik, sebahagian besar golongan belia yang dikaji tanpa mengira kumpulan etnik berpandangan bahawa di era Malaysia baharu ini masyarakat secara umumnya lebih peka kepada isu-isu politik khususnya yang berlaku dalam negara. Dapatan ini mengesahkan pandangan mereka yang melihat tahap literasi politik masyarakat yang semakin tinggi atau semakin celik politik.

Jadual 2. Persepsi terhadap keadaan ekonomi

\begin{tabular}{|c|c|c|c|c|c|c|c|c|}
\hline \multirow[b]{3}{*}{ Perkara } & \multicolumn{8}{|l|}{ Etnik } \\
\hline & \multicolumn{2}{|l|}{ Melayu } & \multicolumn{2}{|l|}{ Cina } & \multicolumn{2}{|l|}{ India } & \multicolumn{2}{|c|}{ Lain-lain } \\
\hline & $\begin{array}{l}\text { Setuju } \\
(\%)\end{array}$ & $\begin{array}{l}\text { Tidak } \\
\text { Setuju } \\
(\%)\end{array}$ & $\begin{array}{l}\text { Setuju } \\
(\%)\end{array}$ & $\begin{array}{l}\text { Tidak } \\
\text { Setuju } \\
(\%)\end{array}$ & $\begin{array}{l}\text { Setuju } \\
(\%)\end{array}$ & $\begin{array}{l}\text { Tidak } \\
\text { Setuju } \\
(\%)\end{array}$ & $\begin{array}{l}\text { Setuju } \\
(\%)\end{array}$ & $\begin{array}{l}\text { Tidak } \\
\text { Setuju } \\
(\%)\end{array}$ \\
\hline $\begin{array}{l}\text { Banyak peluang pekerjaan } \\
\text { golongan belia }\end{array}$ & 19.87 & 53.63 & 7 & 6.63 & 4.5 & 4 & 1.62 & 2.75 \\
\hline Kos sara hidup semakin stabil & 10.13 & 63.37 & 3.75 & 9.87 & 3.63 & 4.87 & 0.75 & 3.63 \\
\hline $\begin{array}{lr}\text { Harga barangan } & \text { dan } \\
\text { perkhidmatan } & \text { semakin } \\
\text { meningkat } & \\
\end{array}$ & 53 & 20.5 & 9.25 & 4.38 & 6.5 & 2 & 3.5 & 0.87 \\
\hline Menyokong pemansuhan GST & 49.25 & 24.25 & 10 & 3.63 & 6.25 & 2.25 & 2.5 & 1.87 \\
\hline $\begin{array}{l}\text { Menerima baik pelaksanaan } \\
\text { SST }\end{array}$ & 30 & 43.5 & 7.5 & 6.12 & 4.75 & 3.75 & 1.25 & 3.13 \\
\hline $\begin{array}{l}\text { Menyokong penetapan kadar } \\
\text { gaji minimum } \mathrm{RM} 1,050 \\
\text { sebulan atau RM5.05 sejam }\end{array}$ & 37.87 & 35.63 & 10 & 3.63 & 6.25 & 2.25 & 2.25 & 2.12 \\
\hline
\end{tabular}

Sumber: Kajian lapangan, 2019

Berdasarkan kepada Jadual 2, sebahagian besar kumpulan belia etnik Melayu dan lain-lain kumpulan etnik berpandangan bahawa di era Malaysia Baharu ini peluang pekerjaan bagi golongan belia masih tidak banyak, sama seperti mana di era pentadbiran kerajaan terdahulu. Manakala bagi kumpulan belia etnik Cina dan India pula, hanya lebih sedikit daripada separuh bilangan responden yang berpandangan peluang pekerjaan bagi golongan belia semakin banyak.

Dari segi kos sara hidup, hampir sebahagian besar responden tidak kira daripada kumpulan etnik mana sekalipun berpandangan bahawa di era Malaysia Baharu ini walaupun sudah berlaku pertukaran kerajaan, kos sara hidup tetap tidak stabil dan terus berlaku peningkatan. Dapatan ini juga seiring dengan pandangan terhadap harga barangan dan perkhidmatan. Sebahagian besar responden tanpa mengira kumpulan etnik berpandangan bahawa harga barangan dan perkhidmatan semakin lama semakin meningkat.

Selain itu, hasil kajian juga menunjukkan sebahagian besar golongan belia yang dikaji tanpa mengira kumpulan etnik menyokong pemansuhan GST yang dikatakan menjadi penyebab utama kenaikan harga barang dan perkhidmatan. Walaupun begitu, lebih dari separuh kumpulan belia etnik Melayu dan lain-lain kumpulan etnik tidak menyambut baik pelaksanaan SST bagi menggantikan GST. Sebaliknya, lebih dari separuh responden belia etnik Cina dan India yang menerima baik pelaksanaan SST sebagai suatu bentuk percukaian baru.

Hasil kajian juga menunjukkan bahawa separuh daripada responden belia etnik Melayu dan lain-lain kumpulan yang menyokong penetapan kadar gaji minimum RM1,050 sebulan atau RM5.05 sejam manakala sebilangan besar responden belia etnik Cina dan India menyatakan pandangan yang sama. Dalam konteks persepsi terhadap keadaan ekonomi ini, masih wujud perbezaan pandangan antara kumpulan belia Melayu dan bukan Melayu. 
Jadual 3. Persepsi tentang sosio-kehidupan

\begin{tabular}{|c|c|c|c|c|c|c|c|c|}
\hline \multirow[b]{3}{*}{ Perkara } & \multicolumn{8}{|l|}{ Etnik } \\
\hline & \multicolumn{2}{|l|}{ Melayu } & \multicolumn{2}{|l|}{ Cina } & \multicolumn{2}{|l|}{ India } & \multicolumn{2}{|c|}{ Lain-lain } \\
\hline & $\begin{array}{l}\text { Setuju } \\
(\%)\end{array}$ & $\begin{array}{l}\text { Tidak } \\
\text { Setuju } \\
(\%)\end{array}$ & $\begin{array}{l}\text { Setuju } \\
(\%)\end{array}$ & $\begin{array}{l}\text { Tidak } \\
\text { Setuju } \\
(\%)\end{array}$ & $\begin{array}{l}\text { Setuju } \\
(\%)\end{array}$ & $\begin{array}{l}\text { Tidak } \\
\text { Setuju } \\
(\%)\end{array}$ & $\begin{array}{l}\text { Setuju } \\
(\%)\end{array}$ & $\begin{array}{l}\text { Tidak } \\
\text { Setuju } \\
(\%)\end{array}$ \\
\hline Kualiti hidup bertambah baik & 19.38 & 54.13 & 7.86 & 5.75 & 5.63 & 2.88 & 1.5 & 2.87 \\
\hline $\begin{array}{l}\text { Perpaduan antara etnik semakin } \\
\text { baik }\end{array}$ & 28.5 & 45 & 9.75 & 3.87 & 6 & 2.5 & 2.38 & 2 \\
\hline $\begin{array}{l}\text { Kebajikan warga emas lebih } \\
\text { terbela }\end{array}$ & 38.75 & 34.5 & 9.63 & 4 & 5.5 & 3 & 3.25 & 1.37 \\
\hline $\begin{array}{l}\text { Banyak ruang penyertaan belia } \\
\text { dibuka dalam pentadbiran } \\
\text { negara }\end{array}$ & 47 & 26.5 & 10.63 & 3 & 6.63 & 1.87 & 2.87 & 1.5 \\
\hline $\begin{array}{ll}\text { Sikap masyarakat } & \text { semakin } \\
\text { terbuka } & \end{array}$ & 56.75 & 16.75 & 11.25 & 2.37 & 7.75 & 0.75 & 3.75 & 0.63 \\
\hline
\end{tabular}

Sumber: Kajian lapangan, 2019

Merujuk kepada Jadual 3 di atas, hasil kajian menunjukkan sebahagian besar kumpulan belia etnik Melayu dan lain-lain kumpulan etnik berpandangan bahawa kualiti hidup di era Malaysia Baharu ini tidak bertambah baik. Sebaliknya, lebih separuh daripada kumpulan belia etnik Cina dan India yang berpandangan kualiti hidup masyarakat di era Malaysia Baharu ini bertambah baik. Begitu juga pandangan terhadap soal perpaduan antara etnik di mana lebih dari separuh kumpulan belia etnik Melayu dan lain-lain kumpulan etnik melihat perpaduan tidak bertambah baik. Manakala sebahagian besar kumpulan belia etnik Cina dan India melihat perpaduan antara etnik semakin bertambah baik.

Dalam konteks kebajikan warga emas, rata-rata responden tanpa mengira kumpulan etnik berpandangan bahawa kebajikan warga emas di era Malaysia Baharu kini adalah lebih terbela. Para responden juga berpandangan bahawa lebih banyak ruang penyertaan kepada belia dibuka dalam pentadbiran negara hari ini. Hal ini kerana mereka melihat lebih ramai muka-muka baru yang terdiri daripada golongan belia telah diberikan peluang untuk memegang jawatan utama dalam pentadbiran negara.

Selanjutnya, sebahagian besar responden tanpa mengira kumpulan etnik berpandangan bahawa sikap masyarakat hari ini adalah semakin terbuka. Keadaan ini adalah selaras dengan anjakan dan perubahan masyarakat Malaysia yang semakin matang dalam menangani pelbagai isu serta sensitiviti yang wujud dalam masyarakat.

Jadual 4 menunjukkan persepsi golongan belia terhadap perkembangan pendidikan dan kemudahan awam di era Malaysia Baharu. Hasil kajian mendapati lebih dari separuh kumpulan belia yang dikaji berpandangan berlaku pembaharuan dalam sistem pendidikan negara di era Malaysia Baharu hari ini. Akan tetapi, lebih dari separuh responden belia etnik Melayu dan Cina yang berpandangan bahawa pelaksanaan sistem pendidikan masih tidak sistematik. Namun begitu, lebih dari separuh responden belia etnik India dan lain-lain kumpulan etnik yang berpandangan pelaksanaan sistem pendidikan kini lebih sistematik berbanding dengan era kerajaan terdahulu.

Dalam konteks infrastruktur dan kemudahan awam, sebahagian besar responden belia etnik Melayu berpandangan infrastruktur dan kemudahan awam sedia ada masih tidak ditambah baik, manakala lebih dari separuh responden belia etnik Cina, India dan lain-lain kumpulan etnik berpandangan infrastruktur dan kemudahan awam sedia ada telah ditambah baik. Pola dapatan 
ini tidak jauh berbeza dengan pandangan terhadap infrastruktur dan kemudahan awam di era Malaysia Baharu ini diperbanyakkan.

Jadual 4. Persepsi terhadap perkembangan pendidikan dan kemudahan awam

\begin{tabular}{|c|c|c|c|c|c|c|c|c|}
\hline \multirow[b]{3}{*}{ Perkara } & \multicolumn{8}{|l|}{ Etnik } \\
\hline & \multicolumn{2}{|l|}{ Melayu } & \multicolumn{2}{|l|}{ Cina } & \multicolumn{2}{|l|}{ India } & \multicolumn{2}{|c|}{ Lain-lain } \\
\hline & $\begin{array}{l}\text { Setuju } \\
(\%)\end{array}$ & $\begin{array}{l}\text { Tidak } \\
\text { Setuju } \\
(\%)\end{array}$ & $\begin{array}{l}\text { Setuju } \\
(\%)\end{array}$ & $\begin{array}{l}\text { Tidak } \\
\text { Setuju } \\
(\%)\end{array}$ & $\begin{array}{l}\text { Setuju } \\
(\%)\end{array}$ & $\begin{array}{l}\text { Tidak } \\
\text { Setuju } \\
(\%)\end{array}$ & $\begin{array}{l}\text { Setuju } \\
(\%)\end{array}$ & $\begin{array}{l}\text { Tidak } \\
\text { Setuju } \\
(\%)\end{array}$ \\
\hline $\begin{array}{ll}\text { Pembaharuan } & \text { sistem } \\
\text { pendidikan negara } & \\
\end{array}$ & 37.37 & 36.13 & 8.63 & 5 & 5.5 & 3 & 2.37 & 2 \\
\hline $\begin{array}{l}\text { Pelaksanaan sistem pendidikan } \\
\text { lebih sistematik }\end{array}$ & 32 & 41.5 & 6.63 & 7 & 5.63 & 2.87 & 2.5 & 1.87 \\
\hline $\begin{array}{l}\text { Infrastruktur dan kemudahan } \\
\text { awam sedia ada ditambah baik }\end{array}$ & 31.75 & 41.75 & 9 & 4.63 & 6 & 2.5 & 2.87 & 1.5 \\
\hline $\begin{array}{l}\text { Infrastruktur dan kemudahan } \\
\text { awam diperbanyakkan }\end{array}$ & 34.75 & 38.75 & 8.87 & 4.75 & 6.38 & 2.13 & 2.5 & 1.87 \\
\hline
\end{tabular}

Sumber: Kajian lapangan, 2019

Berdasarkan kepada data kajian yang telah dibentangkan, terdapat suatu trend persepsi menarik yang boleh diperhalusi. Golongan belia etnik Melayu dilihat lebih objektif dalam mengemukakan pandangan mereka terhadap isu-isu pembangunan komuniti di era Malaysia Baharu ini. Sebagai contoh, mereka melihat pentadbiran di era Malaysia Baharu masih belum mencapai prinsip keadilan yang sewajarnya, belum mencapai tahap ketelusan yang diharapkan mahupun benar-benar bebas dari masalah rasuah, belum berjaya dalam menyediakan peluang pekerjaan kepada golongan belia seperti mana yang dijanjikan dalam pilihan raya, peningkatan kos sara hidup yang gagal diuruskan dengan baik dan kualiti hidup tidak bertambah baik. Senario sedemikian agak ketara berlaku dalam kalangan etnik Melayu apabila mereka terus dihimpit dengan pelbagai permasalahan semasa seperti kemiskinan dan kegagalan mendapatkan peluang pekerjaan. Berdasarkan kepada laporan Berita Harian Online (2019), graduan yang paling ramai menganggur atau bekerja dengan gaji di bawah kelayakan akademik kebanyakannya adalah anak keluarga B40 yang rata-ratanya kumpulan etnik Melayu. Dari itu mereka melihat kerajaan Malaysia Baharu masih lagi gagal memberikan keadilan yang sewajarnya kepada mereka.

Golongan belia etnik Cina dan India dilihat lebih positif dalam menunjukkan sokongan mereka terhadap pemerintahan kerajaan Malaysia Baharu ini. Mereka melihat tindakan penyiasatan yang dikenakan terhadap pemimpin kerajaan terdahulu adalah suatu bentuk pengadilan yang sewajarnya diambil dalam membentuk pentadbiran yang telus dan bebas rasuah, meningkatkan integriti dan pelaksanaan demokrasi yang lebih menyeluruh. Trend sokongan belia Cina dan India terhadap kerajaan Pakatan Harapan (kini), Pakatan Rakyat (dahulu) jelas kelihatan sejak pilihan raya umum ke-13 lagi. Sebagai contoh, pengundi Cina menunjukkan sokongan terhadap pakatan pembangkang (dahulu) berdasarkan kepada beberapa faktor seperti wujudnya peluang yang lebih luas untuk kumpulan etnik mereka mendapatkan jawatan tertinggi dalam kerajaan dan terlibat secara langsung dalam proses pembuatan keputusan negara (Junaidi et. al, 2015). Dengan penguasaan di sektor kerajaan, mereka dapat melaksanakan dasar kesamarataan yang lebih terbuka antara etnik yang dilihat lebih memberikan keadilan untuk kumpulan etnik mereka. Oleh itu mereka berpandangan kerajaan Malaysia Baharu telah membuka lebih banyak ruang penyertaan belia dalam pentadbiran negara. Tidak hairan mengapa kumpulan etnik Cina dan India lebih berpersepsi positif terhadap Malaysia Baharu terutamanya 
dalam agenda pembangunan komuniti yang melibatkan kepentingan kumpulan etnik mereka.

Hasil kajian menunjukkan wujud keterbukaan dalam kalangan belia pelbagai etnik apabila menzahirkan pandangan mereka terhadap sesuatu perkara. Perkembangan ini adalah selaras dengan persepsi terhadap literasi politik yang semakin tinggi, kepekaan masyarakat terhadap isuisu politik yang wujud dalam negara, sikap masyarakat yang semakin terbuka dan perkembangan sistem pendidikan negara. Dalam hal ini, era Malaysia Baharu dilihat telah berjaya menambah baik pembangunan komuniti dalam konteks pembangunan politik dan pendidikan. Sekiranya dimensi ini terus dikembangkan, ia mampu menambah resipi kesedaran bagi mengekalkan kestabilan politik negara pada masa hadapan.

Selain itu, secara tersirat, persepsi yang ditunjukkan oleh kumpulan belia yang dikaji menggambarkan wujudnya persaingan dan perkongsian yang lebih sihat antara kumpulan etnik terhadap isu-isu pembangunan komuniti. Sebagai contoh, wujudnya persaingan sihat apabila terdapat kumpulan etnik yang menerima baik pelaksanaan SST manakala terdapat kumpulan etnik lain yang berpersepsi sebaliknya. Dari segi perkongsian pula dapat dilihat apabila mereka bersama-sama menyokong pemansuhan GST.

\section{Kesimpulan}

Secara keseluruhannya, kajian ini merumuskan bahawa wujudnya variasi persepsi berdasarkan kumpulan etnik dalam kalangan golongan belia, khususnya belia terpelajar yang dikaji terhadap Malaysia Baharu dalam kerangka pembangunan komuniti di Semenanjung Malaysia. Dalam konteks ini, golongan belia etnik Melayu dilihat lebih objektif apabila mengemukakan pandangan mereka bagi isu-isu pembangunan komuniti yang berlaku di persekitaran mereka. Sementara itu, golongan belia etnik Cina dan India pula dilihat lebih positif dalam menunjukkan sokongan mereka terhadap era pemerintahan Malaysia Baharu ini. Pola persepsi mereka lebih terarah untuk mendukung teras masyarakat lebih bersifat civility. Wujudnya persepsi yang berbeza-beza adalah suatu lumrah kehidupan yang dapat menjadikan golongan belia bertambah matang dan bijaksana. Dari itu, hasil kajian ini memberikan suatu gambaran terkini terhadap perkembangan semasa yang berlaku walaupun Malaysia Baharu itu baru sahaja berusia setahun jagung.

\section{Penghargaan}

Artikel ini dihasilkan dari Kajian Persepsi Golongan Belia (Mahasiswa Universiti Awam) terhadap Malaysia Baharu, Geran Putra, Universiti Putra Malaysia. Sehubungan dengan itu kami ini mengucapkan setinggi-tinggi penghargaan dan jutaan terima kasih kepada Universiti Putra Malaysia di atas peruntukan Geran Putra (GP9582600).

\section{Rujukan}

Ahmad Shukri Abdul Hamid. (2015). Konseptualisasi pembangunan komuniti melalui analisis konsep struktur sosial, teori modal sosial dan perspektif realisme kritikal. Jurnal Pembangunan Sosial, 18(Jun), 21-40. 
Berita Harian Online. (2019). Graduan, siswazah miskin, B40 sukar dapat kerja setimpal. Oleh Mohd Azis Ngah; Suzalina Halid dan Fahmy A Rosli, Ahad, 07 Julai 2019. Retrieved from https://www.bharian.com.my/berita/nasional/2019/07/582258/eksklusif-graduan-siswazahmiskin-b40-sukar-dapat-kerja-setimpal

Berita Harian Online. (2018). Kerajaan baharu dan hala tuju politik negara. Oleh Mansor Mohd Noor, Sabtu, 19 Mei 2018. Retrieved from https:/www.bharian.com.my/kolumnis/ 2018/05/427534/kerajaan-baharu-dan-hala-tuju-politik-negara

Berita Harian Online. (2019). Perutusan Perdana Menteri sempena setahun kerajaan Pakatan Harapan. Khamis, 9 Mei 2019. Retrieved from https://www.bharian.com.my/berita/nasional/ 2019/05/562120/perutusan-perdana-menteri-sempena-setahun-kerajaan-pakatan-harapan

Fendley, K., \& Christenson, J.A. (2009). Rural reflation: An idea for community development. Journal of the Community Development Society, 20(1), 103-115.

Haines, A. (2009). Asset-based community development. Dlm. Phillips \& Pittman (Edt.), An introduction to community development (hlm. 38-48). New York: Routledge.

Junaidi Awang Besar, Rosmadi Fauzi, \& Amer Saifude Ghazali. (2015). Politik etnik di Kuala Lumpur: Kajian tanggapan pengundi dalam kalangan penghuni Program Perumahan Rakyat (PPR) pasca Pilihan Raya Umum 2013. Geografia-Malaysian Journal of Society and Space, 11(7), 33-44.

MalaysiaKini Online. (2019). MBM: Had umur belia patutnya 35, bukan 30. Rabu, 03 Julai 2019. Retrieved from https://www.malaysiakini.com/news/482186

Mansor Mohd Noor. (2012). Kerencaman Sosial dan Penipisan Batas Etnik: Kepelbagaian Etnik dan Perkongsian Hidup Bersama di Malaysia. Siri Syarahan Umum Perdana. Bangi: Penerbit Universiti Kebangsaan Malaysia.

Mohammad Shatar Sabran. (2003). Model Pembangunan Komuniti. Pertanika Journal of Social Science \& Humanities, 11(2), 135-145.

Mohd Mahadee Ismail. (2015). Pendidikan sivik dan pembinaan etos nasional dalam kalangan alumni Program Latihan Khidmat Negara (PLKN): Kajian ke atas mahasiswa Universiti Putra Malaysia (UPM), (Tesis Doktor Falsafah). Retrieved from Institut Kajian Etnik, Universiti Kebangsaan Malaysia.

Phillips, R., \& Pittman, H.R. (2009). A framework for community and economic development. Dlm. R. Phillips, \& H.R. Pittman, (Edt.), An introduction to community development (hlm. 3-19). New York: Routledge.

Sanders, I. T. (1989). The concept of community development. Dlm. L.J. Cary, (Edt.), Community development as a process (hlm. 9-31). Missouri: University of Missouri Press.

Utusan Online. (2014). Had umur belia 15-30 tahun bermula 2018. Oleh Lilis Suriani Omar, Selasa, 18 November 2014. Retrieved from https://www.utusan.com.my/berita/nasional/hadumur-belia -15-30-tahun-bermula-2018-1.26083

Utusan Online. (2018). Harapan terhadap Malaysia Baharu. Oleh Noor Mohamad Shakil Hameed, 16 Julai 2018. Retrieved from https://www.utusan.com.my/rencana/utama/ harapan- terhadap-malaysia-baharu-1.709614

Utusan Online. (2018). Pertimbangan antara SST - GST. Oleh Rohami Shafie, Ahad, 22 Julai 2018. Retrieved from https://www.utusan.com.my/rencana/utama/pertimbangan-antara-sstgst-1.713707 